\title{
MUC-1 expression in pleomorphic adenomas using two human milk fat globule protein membrane antibodies (HMFG-1 and HMFG-2)
}

\author{
Santa PONCE-BRAVO, Constantino LEDESMA-MONTES, Maricela GARCÉS-ORTÍZ
}

Clinical Oral Pathology Laboratory. División de Estudios de Posgrado e Investigación. Facultad de Odontología, Universidad Nacional Autónoma de México, México, D.F. - México.

Corresponding address: Constantino Ledesma-Montes - Ciprés \#169-2 - Col. Vergel-Coapa - México - D.F. - 14320 - México - Phone/Fax: +52 55-56711389 - e-mail: cledezma@unam.mx

Submitted: November 26, 2014 - Modification: January 28, 2015 - Accepted: March 23, 2015

ABSTRACT Peomorphic adenoma (PA) is the most common salivary gland tumor and its microscopic
features and histogenesis are a matter of debate. Human milk fat globule protein
membrane (HMFG) monoclonal antibodies (MoAbs) comprise a set of antibodies against the
mucin 1 (MUC-1) protein detected in several salivary gland tumors. Objective: The aim of
this study was to assess the immunoexpression of the PA neoplastic cells to MUC-1 protein
using HMFG-1 and HMFG-2 MoAbs, contrasting these results with those from normal salivary
gland tissue. Material and Methods: Immunohistochemical detection of MUC-1 protein
using HMFG-1 and HMFG-2 MoAbs was made in $5 \mu$ m thick, paraffin embedded slides, and
the avidin-biotin method was used. Results: Positivity to HMFG-1 and HMFG-2 MoAbs was
found in ductal, squamous metaplastic and neoplastic myoepithelial cells, keratin pearls
and intraductal mucous material. Two kinds of myoepithelial cells were identified: classic
myoepithelial cells around ducts were negative to both MoAbs, and modified myoepithelial
cells were positive to both MoAbs. This last cellular group of the analyzed tumors showed
similar MUC-1 immunoexpression to ductal epithelial cells using both HMFG antibodies.
Intraductal mucous secretion was also HMFG-1 and HMFG-2 positive. Conclusions: Our
results showed there are two kinds of myoepithelial cells in PA. The first cellular group is
represented by the different kinds of neoplastic myoepithelial cells and is HMFG-positive.
The second one is HMFG-negative and represented by the neoplastic myoepithelial cells
located around the ducts.

Key words: Salivary gland tumors. Pleomorphic adenoma. MUC-1 mucin. Human milk fat globule membrane. Myoepithelial cell.

\section{INTRODUCTION}

Pleomorphic adenoma (PA) is the most common epithelial neoplasm arising in the salivary gland tissue; it is more frequently found in palate and is more common in males ${ }^{7}$. Racial differences among age, gender and location have been reported $7,15,16$.

Human milk fat globule membrane (HMFG) is part of the apical cell membrane of the secretory mammary cells and it contains several differentiation antigens ${ }^{3}$. Two of them are HMFG-1 and HMFG-2 monoclonal antibodies (MoAbs), which are directed against the oligosaccharide side chains of glycoprotein components of this structure ${ }^{1}$.
Anti-HMFG-1 and -2 comprise a set of monoclonal antibodies against the mucin 1 (MUC-1) protein and they have been found in breast malignant tumors 25 and in different benign tumors and malignancies from several organs ${ }^{1,5,6,8-13,17,27}$. The presence of HMFG membrane-derived antigens has been correlated with differentiation and prognosis ${ }^{13,26,27}$. To date, the presence of the epitopes of MUC-1 protein using HMFG-1 and -2 monoclonal antibodies has been demonstrated in several salivary gland tumors $4,19,23,28$. We were able to find only few studies on the expression of HMFG-1 in pleomorphic adenomas $4,21,24$.

The aim of this study was to assess the 
immunoexpression of the PA neoplastic cells to MUC-1 protein using HMFG-1 and HMFG-2 MoAbs and to compare these results with those from normal salivary gland tissue.

\section{MATERIAL AND METHODS}

All examples of salivary gland tumors were collected from the files of the Clinical Oral Pathology Laboratory of the Facultad de Odontología of Universidad Nacional Autónoma de México in Mexico City, and PA cases were separated. Hematoxylin and eosin (H\&E) stained slides were available in every case. All cases were microscopically reviewed and diagnoses were re-evaluated according to the World Health Organization (WHO) International Classification of Salivary Gland Tumours ${ }^{2}$. Additional sections were stained with Periodic acid-Schiff (PAS), alcian blue and Hale's coloidal iron stains. Normal tissues from labial, submandibular and parotid salivary glands were used as controls.

Cells in PAs were classified as epithelial and myoepithelial cells (MyECs). Epithelial cells were categorized as ductal and non-ductal cells, this last cellular set being formed by metaplastic squamous cells, keratin pearls and cells in solid epithelial-like areas. MyECs were divided into two sets: those found around the ductal structures were named classic myoepithelial cells (CMyECs); modified myoepithelial cells (MMyECs) were those found forming variable sized groups of spindle-shaped, plasmacytoid (hyaline) clear cells. MyECs associated to chondroid, myxoid, hyaline or mucoid areas were also considered in the last group. MyECs in normal salivary glands were all considered as CMyECs.

Methodology for synthesis and immunological features of the HMFG-1 and -2 MoAbs used in this study was described in detail by Arklie, et al. ${ }^{1}$ (1981), Ceriani, et al. ${ }^{3}$ (1979) and TaylorPapadimitrou, et al. ${ }^{26}$ (1981). Immunohistochemical detection of MUC-1 protein using HMFG-1 and HMFG-2 MoAbs was conducted according to a previous publication ${ }^{14}$. Briefly, immunostaining was made in $5 \mu$ thick, paraffin embedded slides, later rinsed with PBS solution. All sections were treated with $\mathrm{H}_{2} \mathrm{O}_{2}$ for one hour to inhibit endogenous peroxidase activity and incubated for $10 \mathrm{~min}$ with $10 \%$ normal horse serum. Then, they were incubated overnight at $4^{\circ} \mathrm{C}$ with HMFG-1 (1:100 dilution) and HMFG-2 (1:40 dilution) MoAbs and the avidin-biotin method was used. Peroxidase activity was detected using 3,3'-diaminobenzidine tetrahydrocloride as the substrate and all slides were counterstained with Harris hematoxylin. Control was normal labial salivary gland tissue treated with the same techniques. Negative controls were made omitting the antibody. Immunostaining grading was the same used in a previously published study ${ }^{14}$ : negative $=0 ;$ slight $=1 ;$ moderate $=2$; strong $=3$; very strong $=4$.

\section{RESULTS}

\section{Microscopic findings}

No morphological alterations were seen in the labial, submandibular and parotid gland examined tissues. Microscopic review of the 24 PA analyzed cases showed they were composed by different

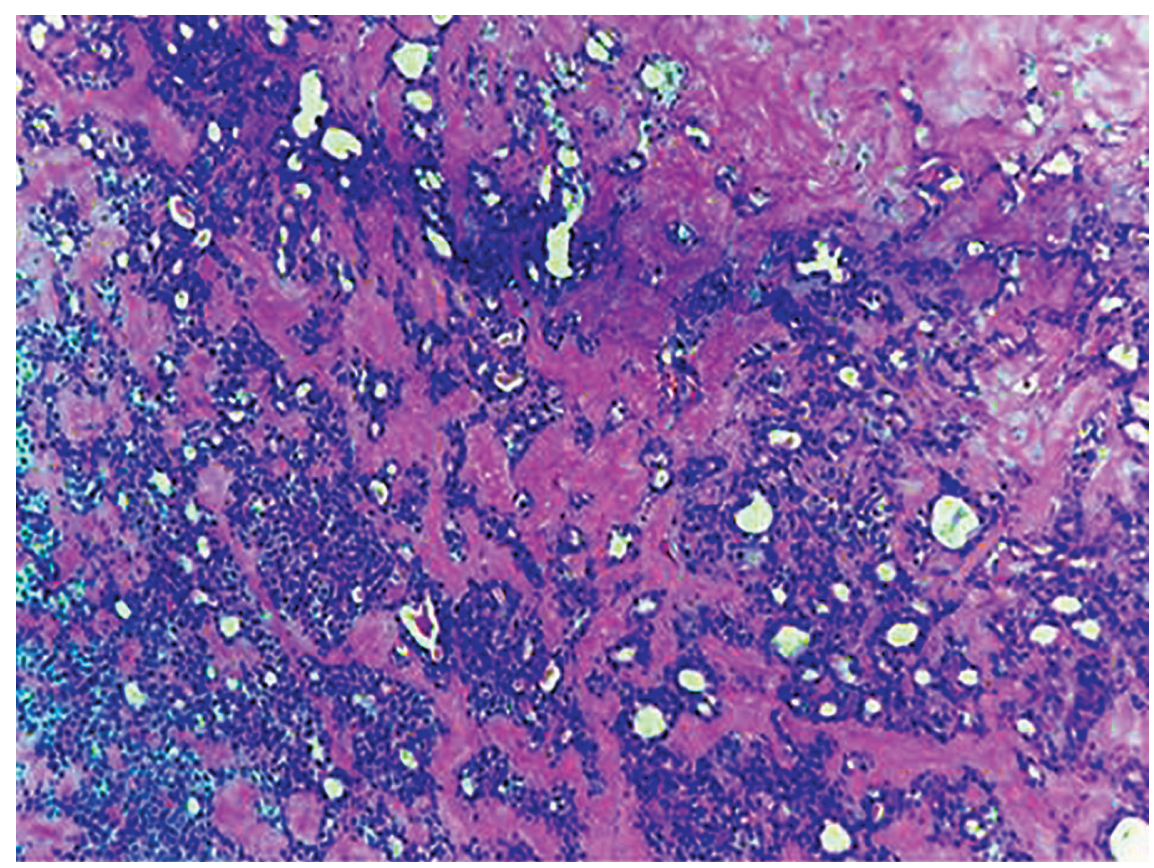

Figure 1- Photomicrograph showing the classic microscopic features of a pleomorphic adenoma. 100×. Hematoxylin \& eosin 
structures in variable quantities: sheets and groups of epithelial polygonal cells, ductiform structures, squamous metaplastic cells, keratin pearls; MMyECs were fusiform, hyaline and clear, combined with variable quantities of hyaline, mucoid, myxoid

\begin{tabular}{|c|c|c|}
\hline TYPE OF CELL & HMFG-1 & HMFG-2 \\
\hline \multicolumn{3}{|c|}{ LABIAL GLANDS } \\
\hline Mucous acinar cells & $1-2$ & $1-2$ \\
\hline Ductual cells & 1 & 1 \\
\hline CMyECs & 0 & 0 \\
\hline Intraductal secretion & 0 & 0 \\
\hline \multicolumn{3}{|c|}{ SUBMANDIBULAR GLANDS } \\
\hline Mucous cells & $2-4$ & 0 \\
\hline Serous cells & $2-3$ & 0 \\
\hline Striated duct cells & $1-3$ & $1-4$ \\
\hline Intralobular duct cells & $3-4$ & $1-4$ \\
\hline CMyECs & 0 & 0 \\
\hline Intraductual secretion & $1-2$ & $1-2$ \\
\hline \multicolumn{3}{|c|}{ PAROTID GLANDS } \\
\hline Serous cells & 1 & 1 \\
\hline Ductal cells & 3 & $1-2$ \\
\hline CMyECs & 0 & 0 \\
\hline Intraductal secretion & 2 & $1-2$ \\
\hline
\end{tabular}

CMyECs=classic myoepithelial cells

Immunoreactivity: 0 =negative; 1=slight; 2=moderate; 3=strong; 4=very strong

Figure 2- Immunoexpression in normal control salivary glands and chondroid areas accompanied by eosinophilic coagula within the ducts (Figure 1).

\section{Immunohistochemical findings}

Data on the immunohistochemical findings is presented in Figure 2.

\section{Normal salivary glands}

In labial salivary glands, immunopositivity to both MoAbs was $1+$ in the ductal cells, and it varied from $1+$ to $2+$ in the mucous acinic cells. No immunostaining was observed in the intraductal secretion and CMyECs with both employed MoAbs (Figure 3).

In submandibular salivary gland (SMSG) specimens, HMFG-1 immunostaining varied from $1+$ to $3+$ in the ductal striated cells and from $3+$ to $4+$ in the intralobular ductal cells. Serous acini were $2+$ to $3+$ and mucous secreting cells varied from $2+$ to $4+$. Intraductal secretion immunostaining varied from $1+$ to $2+$ (Figure $4 \mathrm{~A}$ ). With HMFG-2, ductal cells in SMSG had a staining intensity from $1+$ to $4+$ and there was negative staining in both the serous and mucous secretory cells. Intraductal secretions stained $1+$ to $2+$ (Figure 4B).

In parotid salivary glands, HMFG-1 immunostaining was $1+$ in some acinic cells and $3+$ in ductal cells. Immunopositivity in secretion was $2+$ (Figure 5A). In parotid gland cells, immunopositivity to HMFG-2 antibody was from $1+$ to $2+$ in the ductal cells and more intense in their apical portions. There was $1+$ positivity in some groups of acinar cells and immunostaining in intraductal secretions was from $1+$ to $2+$ (Figure 5B). MUC-1 immunoexpression is shown in Figure 2.

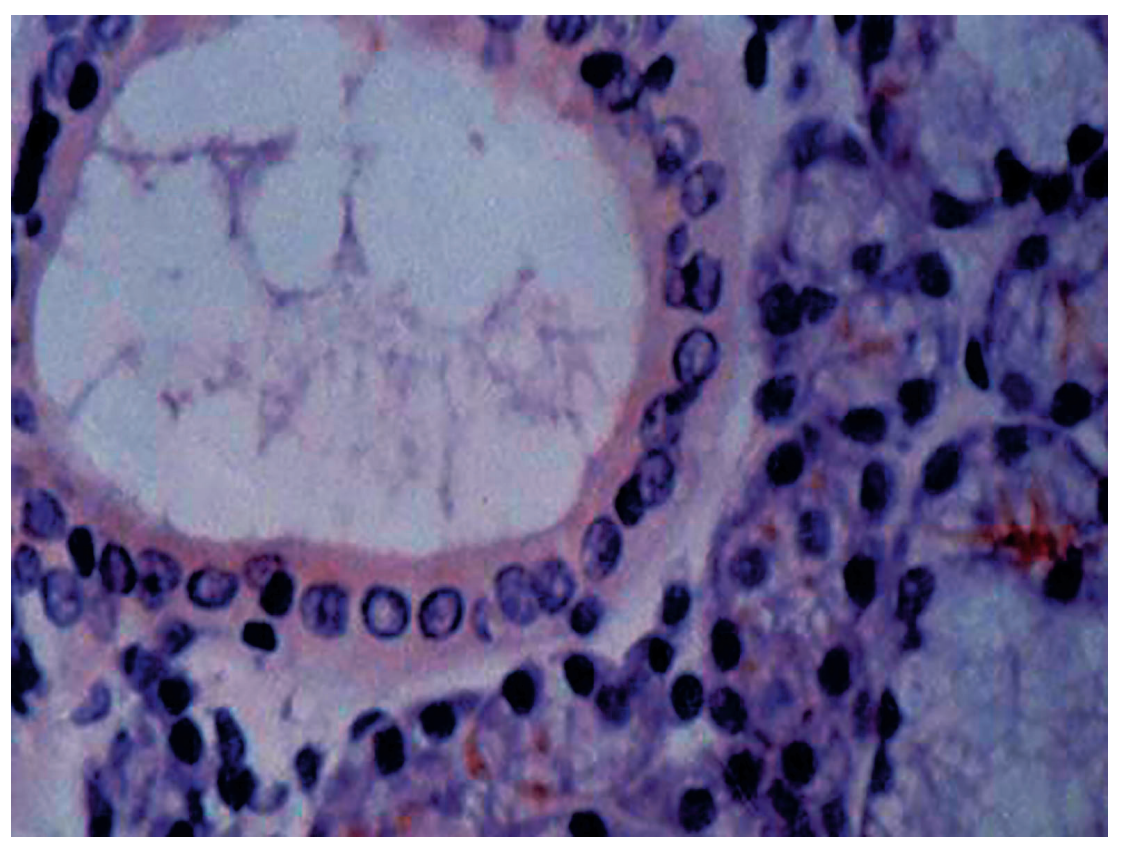

Figure 3- Normal labial salivary gland tissue showing slight immunoexpression to HMFG-2 antibody. 400x. HMFG-2 MoAb. Avidin-biotin method 


\section{Pleomorphic adenoma cases}

Not all the slides from the studied PA cases were stained with both HMFG antibodies since, despite several efforts, four cases were negative. Three PAs were negative to HMFG-1 MoAb and one PA did not stain with HMFG-2 MoAb. No differences in immunostaining intensity were found when it was correlated with gender, age or location.

\section{HMFG-1}

In the positive tumors, immunostaining intensity to HMFG-1 varied from slight to strong. In seven cases $(31.8 \%)$, slight intensity was found, in 12 cases $(54.6 \%)$ it was moderate, and in three
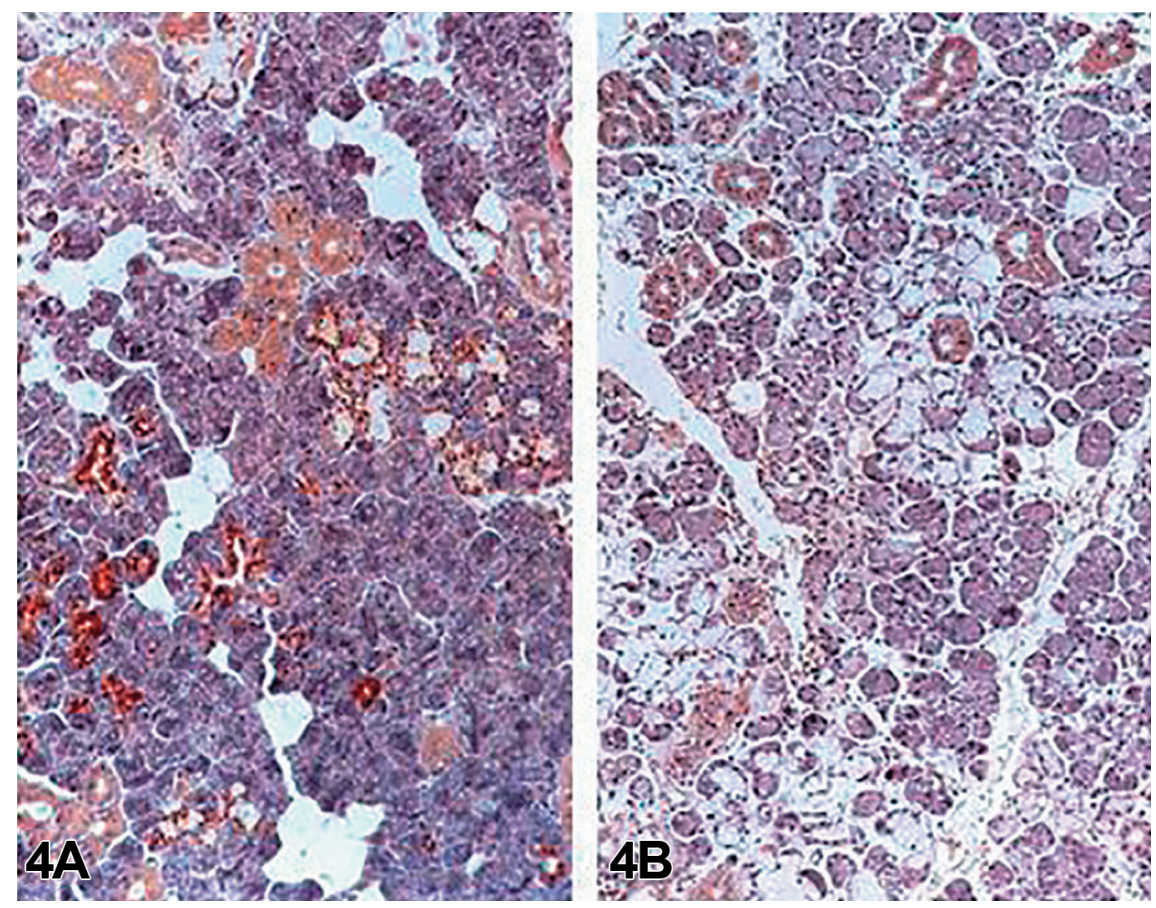

Figure 4- MUC-1 immunoexpression in normal submandibular salivary gland tissue. A) HMFG-1 immunopositivity. 100×. B) Immunoexpression to HMFG-2. 100x. HMFG-1 and HMFG-2 MoAbs. Avidin-biotin method
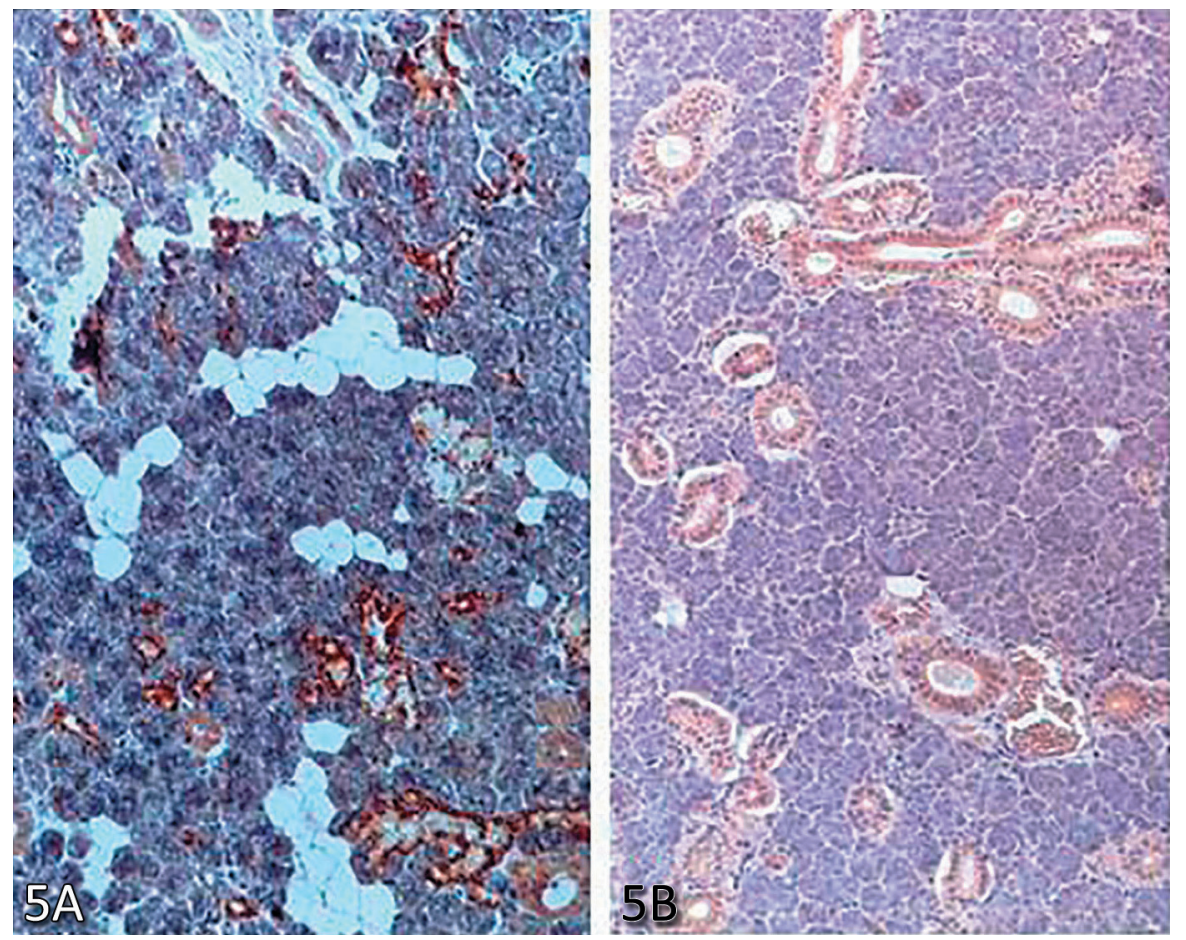

Figure 5- MUC-1 immunoexpression in normal parotid salivary gland tissue. A) HMFG-1 immunopositivity. 100×. B) Immunoexpression to HMFG-2. 100×. HMFG-1 and HMFG-2 MoAbs. Avidin-biotin method 

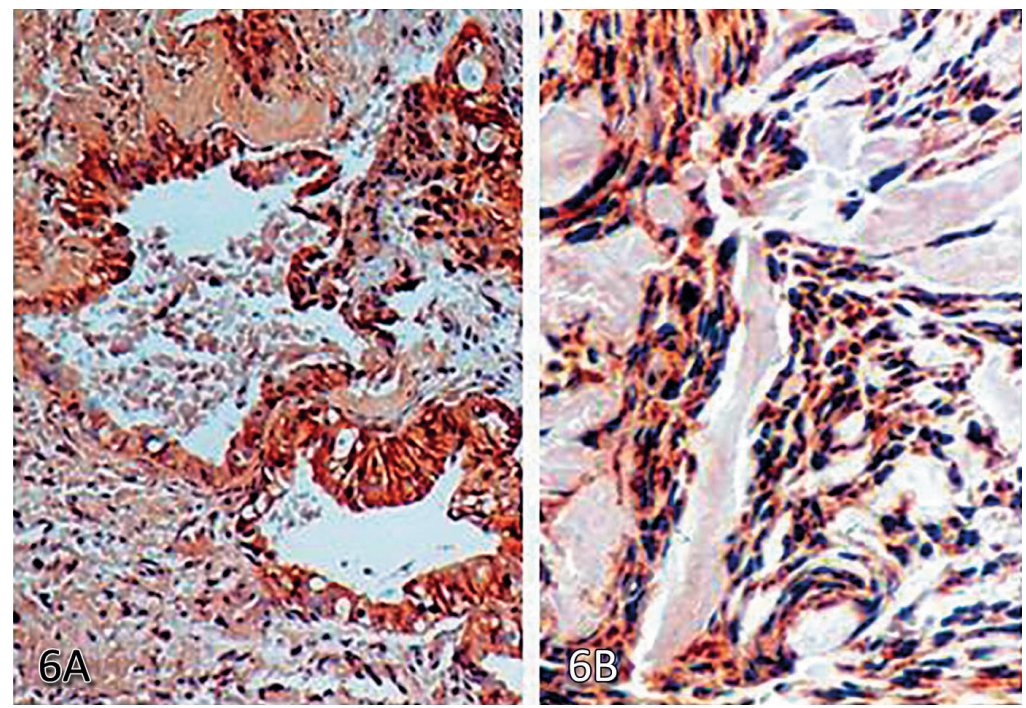

Figure 6- A) Neoplastic ductal structures showing variable immunoexpression to HMFG-1 antibody. No staining is shown by the myoepithelial cells around the ducts. 400×. B) Neoplastic cells with moderate to intense immunostaining. 400×. All photomicrographs. HMFG-1 MoAb. Avidin-biotin method

\begin{tabular}{|c|c|c|c|}
\hline TYPE OF CELL & & HMFG-1 & HMFG-2 \\
\hline Ductal & & $1-3$ & $1-3$ \\
\hline CMyECs & & 0 & 0 \\
\hline Intraductal & & 1 & 1 \\
secretion & & & \\
\hline & Polyhedral & $2-3$ & $2-3$ \\
\hline & Squamous & $1-3$ & $1-3$ \\
\hline Modified & Keratin & $1-3$ & $1-3$ \\
myoepithelial & Pearls & $1-3$ & $1-3$ \\
cells & Fusiform & $1-3$ & $1-3$ \\
& Plasmacytoid & 2 & $1-2$ \\
& Clear & $1-2$ & 1 \\
& Chondroid & 1 & 1 \\
& Myxoid & 1 & 1 \\
\hline
\end{tabular}

CMyECs=classic myoepithelial cells

Immunoreactivity: $0=$ =negative; 1 =slight; 2=moderate; $3=$ strong.

Figure 7- MUC-1 immunoexpression in pleomorphic adenoma cells

cases (13.6\%) intensity was strongly expressed. Positivity was found in the neoplastic ductal cells. Immunostaining of these cells varied from slight to strong and it was slight in the intraductal secretion (Figure 6A). Polyhedral non-ductal cells showed moderate to strong immunoreaction (Figure 6B). CMyECs were not stained with this MoAb. Other MMyECs showed slight to intense immunoreactivity. Characteristically, neoplastic interstitial tissue stained from slight to moderate with this MoAb. Detailed immunoreactivity of these cells is shown in Figure 7.

\section{HMFG-2}

In 24 positive cases, immunoreactivity varied from slight to strong. In 5 cases it was slight $(20.8 \%) ; 11$ cases $(45.8 \%)$ showed moderate intensity and in eight cases (33.3\%) it was strong. Ductal neoplastic cells immunostaining varied from slight to strong and, as in HMFG-1 MoAb, CMyECs did not show immunoreaction. Intraductal secretion showed slight immunoreactivity (Figure 8A). MMyECs immunoreactivity also varied from slight to strong (Figure 8B). Immunoreactivity of these cells to HMFG-2 MoAbs is shown in Figure 7. Data in this table show that MMyECs and ductal epithelial cells in PAs presented similar MUC-1 immunoexpression using both HMFG antibodies.

\section{DISCUSSION}

This is the first report on the presence of MUC1 protein in PAs using both HMFG-1 and HMFG-2 MoAbs in pleomorphic adenomas. Findings on the existence of these proteins in normal submandibular and parotid salivary gland tissues were previously reported and discussed by our study group ${ }^{14}$. In this study, immunopositivity to both antibodies was found in normal secretory and ductal cells from all three tested kinds of salivary glands and negativity in the CMyECs surrounding these structures.

The milk fat globule membrane is an important component of the mammalian milk, it contains several proteins and glycoproteins, which are useful markers for cellular differentiation in diverse tissues and were identified in several kinds of tumors $1,3,5,6,8-13,17,26,27$. The HMFG-1 monoclonal antibody mainly reacts with lactating breast, and has been found in several benign and malignant tumors $1,5,6,12,13,17,23$. The HMFG-2 antigen is strongly 


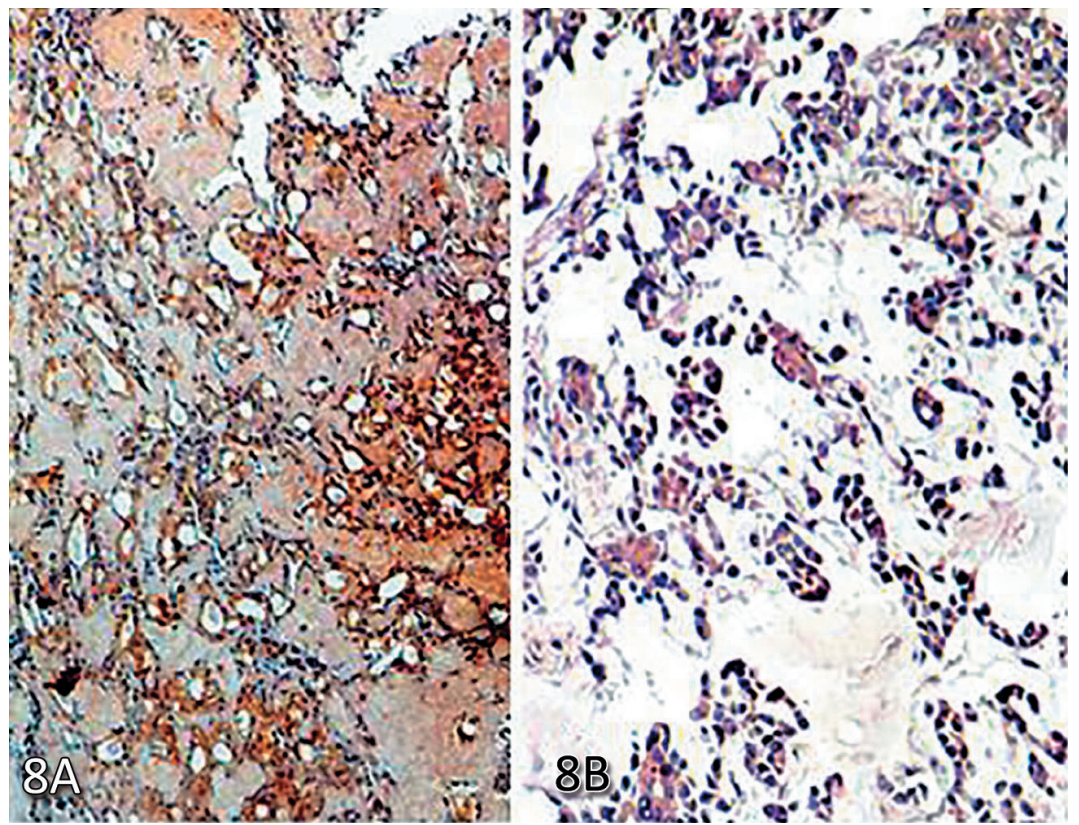

Figure 8-A) Ductiform structures showing slight immunostaining in the secreted material and no staining in the myoepithelial cells. $100 \times$. B) Numerous neoplastic cells with slight to moderate immunostaining. 200×. All photomicrographs. HMFG-2 MoAb. Avidin-biotin method

expressed in carcinomas ${ }^{9-12,22,23,26,27 .}$.

MoAbs tested in this study have been used in a limited number of salivary gland tumours ${ }^{18-24,28}$, including those using PA neoplastic tissue ${ }^{4,5,24}$.

In the Hamada, et al. ${ }^{4}$ (2004) study, none of 40 non-recurrent PA cases were positive to HMFG-1. In this article, the authors claimed that only one recurrent PA case was positive to HMFG-1, but their table indicates that two cases showed positivity (one parotid and one submandibular tumor). These results contrast with those from our study; we found immunoexpression to both antibodies in both neoplastic cell compartments of the analyzed PAs. In the neoplastic epithelial compartment, positive cells were: ductal epithelial cells, epithelial-like cells in solid areas, metaplastic squamous epithelial cells and keratin pearls. Also, in the mesenchymallike neoplastic compartment, cells composing the hyaline, myxoid and chondroid zones and the fusiform, plasmacytoid and clear MMyECs were also stained with variable intensities. Our findings are similar to those described in other works, which found immunoexpression with these antibodies in similar structures from different neoplasms s,17,28. $^{2}$.

Our results are quite different from those obtained in the study of Hamada, et al. ${ }^{4}$ (2004). Theirs showed that only one (maybe two) PA case was positive to HMFG-1; in contrast, our study showed that $88 \%$ of our PAs were positive. Additionally, 23 of our 24 PA tested cases presented immunopositivity to HMFG-2.

In this study, we found that both HMFG antigens were expressed in every cell of the neoplastic epithelial compartment (neoplastic ductal and non- ductal cells) and in the MMyEC compartment of the analyzed PAs. Similarities in immunopositivity to MUC-1 antigens in the whole neoplastic epithelial cells and MMyECs suggest that a common cell gives origin to both sets of neoplastic cells. As it was reported in this and in our previous study ${ }^{14}$, positive immunoexpression to MUC-1 protein with both HMFG antibodies was found in the cytoplasm of the acinar cells of normal labial, submandibular and parotid glands. Considering that normal acinar salivary gland cells are completely differentiated cells, this finding does not support the hypothesis that acinar cells may play a role in the histogenesis of PAs.

Results from this study show that CMyECs surrounding ducts in normal labial salivary glands were negative to both HMFG antibodies and that in studied PA samples, neoplastic CMyECs were negative too. These findings suggest that normal CMyECs are not the ancestor cells during PAs development and that their role in the ontogenesis of these neoplasms needs to be clarified. In contrast, we found that all MMyECs in the studied PAs (fusiform, hyaline and clear cells and hyaline, mucoid, myxoid and chondroid tissue-associated cells) stained positively with both tested antibodies. The above mentioned findings suggest that MMyECs are responsible in part for the wide histologic variation of these neoplasms.

\section{ACKNOWLEDGMENTS}

The authors are especially indebted to Dr. Joyce Taylor-Papadimitriou (Imperial Cancer 
Research Fund, London, UK) for kindly supplying the antibodies. Santa Ponce-Bravo owes a special debt of gratitude to Dr. Elisa M. Durban, whose personal friendship, scientific advice and assistance were invaluable.

\section{REFERENCES}

1- Arklie J, Taylor-Papadimitrious J, Bodmer W, Egan M, Millis R. Differentiation antigens expressed by epithelial cells in the lactating breast are also detected in breast cancers. Int J Cancer. $1981 ; 28: 23-9$.

2- Barnes L, Eveson JW, Reichart PA, Sidransky D, eds. Pathology \& genetics: head and neck tumours. Lyon: IARC Press; 2005. 435 p.

3- Ceriani RL, Thompson K, Peterson A, Abraham SA. Surface differentiation of antigens of human mammary epithelial cells carried on human milk fat globule. Proc Natl Acad Sci U S A. 1979;74:582-6.

4- Hamada T, Matsukita S, Goto M, Kitajima S, Batra SK, Irimura T, et al. Mucin expression in pleomorphic adenoma of salivary gland: a potential role for MUC1 as a marker to predict recurrence. J Clin Pathol. 2004;57:81321.

5- Johnson JS, Lee JA, Cotton DW, Lee WR, Parsons MA. Dimorphic immunohistochemical staining in ocular sebaceous neoplasms: a useful diagnostic aid. Eye (Lond). 1999;13:104-8.

6- King JA, Tucker JA. Evaluation of membranous staining of mesothelioma. Cell Vis. 1998;5:24-7.

7- Ledesma-Montes C, Garcés-Ortíz M. Salivary gland tumors in a Mexican sample. A retrospective study. Med Oral. 2002;7:324-30. 8- Ljung G, Lennernäs B, Nordgren $H$, Holmberg A, Westlin JE, Nilsson $S$, et al. Human milk fat globule antigen 1 (HMFG1) expression in prostatic carcinoma and immunotargeting with a radiolabelled monoclonal anti-HMFG1 antibody. Anticancer Res. 2000;20:2321-4.

9- Ma CK, Zarbo RJ, Frierson HF Jr, Lee MW. Comparative immunohistochemical study of primary and metastatic carcinomas of the liver. Am J Clin Pathol. 1993;99:551-7.

10- Mariani-Costantini R, Colnaghi MI, Leoni F, Mènard S, Cerasoli $\mathrm{S}$, Rilke F. Immunohistochemical reactivity of a monoclonal antibody prepared against human breast carcinoma. Virchows Arch A Pathol Anat Histopathol. 1984;402:389-404.

11- Mills SE, Wolfe JT $3^{\text {rd }}$, Weiss MA, Swanson PE, Wick MR, Fowler JE Jr, et al. Small cell undifferentiated carcinoma of the urinary bladder. A light-microscopic, immunocytochemical and ultrastructural study of 12 cases. Am J Surg Pathol. 1987;11:60617.

12- Oka K, Hoshi T, Nakano T, Arai T. Expression of human milk fat globule-1 in carcinomas of the uterine cervix treated with radiation therapy alone. Arch Pathol Lab Med. 1992;116:955-9.
13- Parham DM, Slidders W, Robertson AJ. Quantitation of human milk fat globule (HMFG1) expression in breast carcinoma and its association with survival. J Clin Pathol. 1988;41:875-9.

14- Ponce-Bravo S, Ledesma-Montes C, Morales-Sánchez I. MUC-1 mucin in normal human salivary glands detected by HMFG-1 and HMFG-2 monoclonal antibodies. APMIS. 2008;116:93-8.

15- Rippin JW, Potts AJ. Intra-oral salivary gland tumors in the West Midlands. Br Dent J. 1992;173:17-9.

16- Rivera-Bastidas $\mathrm{H}$, Ocanto RA, Acevedo AM. Intraoral minor salivary gland tumors: a retrospective study of 62 cases in a Venezuelan population. J Oral Pathol Med. 1996;25:1-4.

17- Saga K. Histochemical and immunohistochemical markers for human eccrine and apocrine sweat glands: an aid for histopathologic differentiation of sweat gland tumors. J Investig Dermatol Symp Proc. 2001;6:49-53.

18- Simpson RH, Clarke TJ, Sarsfield PTL, Babajews AV. Salivary duct adenocarcinoma. Histopathology. 1991;18:229-35.

19- Simpson RH, Clarke TJ, Sarsfield PT, Gluckman PG. Epithelialmyoepithelial carcinoma of salivary glands. J Clin Pathol. 1991;44:419-23.

20- Simpson RH, Clarke TJ, Sarsfield PT, Gluckman PG, Babajews AV. Polymorphous low-grade adenocarcinoma of the salivary glands: a clinicopathological comparison with adenoid cystic carcinoma. Histopathology. 1991;19:121-9.

21- Simpson RH, Jones H, Beasley P. Benign myoepithelioma of the salivary glands: a true entity? Histopathology. 1995;27:1-9. 22- Simpson RH, Pereira EM, Ribeiro AC, Abdulkadir A, Reis-Filho JS. Polymorphous low-grade adenocarcinoma of the salivary glands with transformation to high-grade carcinoma. Histopathology. 2002;41:250-9.

23- Simpson RH, Sarsfield PT, Clarke T, Babajews AV. Clear cell carcinoma of minor salivary glands. Histopathology. 1990;17:4338.

24- Soares AB, Demasi AP, Altemani A, Araújo VC. Increased mucin 1 expression in recurrence and malignant transformation of salivary gland pleomorphic adenoma. Histopathology. 2011;58:377-82.

25- Taylor-Papadimitriou J, Peterson JA, Arklie J, Burchell J, Ceriani $\mathrm{RL}$, Bodmer WF. Monoclonal antibodies to epithelium-specific components of the human milk fat globule membrane: production and reaction with cells in culture. Int J Cancer. 1981;28:17-21.

26- Wrba F, Reiner A, Markis-Ritzinger E, Holzner JH, Reiner G, Spona J. Prognostic significance of immunohistochemical parameters in breast carcinomas. Pathol Res Pract. 1988;183:27783.

27- Yang GY, Liao J, Cassai ND, Smolka AJ, Sidhu GS. Parietal cell carcinoma of gastric cardia: immunophenotype and ultrastructure. Ultrastruct Pathol. 2003;27:87-94.

28- Zotter S, Hageman PC, Lossnitzer A, van den Tweel J, Hilkens J, Mooi WJ, et al. Monoclonal antibodies to epithelial sialomucins recognize epitopes at different cellular sites in adenolymphomas of the parotid gland. Int J Cancer Suppl. 1988;3:38-44. 